\title{
FROM THE BRICKFIELDS OF EGYPT
}

\author{
By K. A. KITCHEN
}

In early Hebrew tradition, one of the most evocative and familiar topoi for us moderns - heard in childhood and studied later - is that of the hapless Hebrew slaves toiling in the brickfields of the Egyptian East Delta under the lash of Pharaoh's taskmasters (Ex. 1:11-14; 5:5ff.). Much is made of the date, the route, the historical and theological significance of the oppression and exodus (and rightly so), but little more than a glance is usually spared for details of those toils preceding the exodus that were so painfully etched in the Hebrews' memories. The subject is hardly a burning issue, but is perhaps not unworthy of some modest attention based on first-hand material either quite new or long available but much neglected.

First, I outline textual references to brick-production in pharaonic Egypt; the vast archaeological material lies beyond the needfully limited purview of this paper. ${ }^{1}$

From the Old Kingdom ('Pyramid Age', third millennium $B C$ ) comes the earliest body of original papyrus documents. These are fragments of the meticulously-compiled accounts from the pyramid-temple of king Neferirkare at Abusir, a little north-west of ancient Memphis. ${ }^{2}$ Besides the neatlyruled tables of daily and monthly duties of priests and temple

${ }^{1}$ Egyptian building modes in general, $c f . \mathrm{S}$. Clarke and R. Engelbach, Ancient Egyptian Masonry: the Building Craft, London (1930). The basic physical cvidence on nature, types and uses of brick in ancient Egypt has been dealt with by A. J. Spencer in his doctoral thesis at Liverpool.

${ }^{2}$ The Abusir papyri, divided among several museums. Introduction, photos and hieroglyphic transcriptions are published in Mme. P. Posener-Krieger and J.-L. de Cenival, Hieratic Papyri in the British Museum, 5th Series, British Museum, London (1968); translation and commentary, forthcoming. These accounts date from the reigns of Isesi to Teti $(c .2380-2340 \mathrm{BC})$, up to a century after the death of Neferirkare. 
staff, the inventories of temple-furnishings, preparations for festivals, etc., the miscellaneous accounts include one tabulation in three sections, the first of which relates to bricks. ${ }^{3}$ Here, a horizontal rubric (seemingly in red ink) runs: '[Accou]nt of brick(s) brought into the workshop-stores'. Below this are the remnants of names of 17 royal officials of very varied employment probably followed by amounts of bricks (now lost). At the end, an eighteenth column has the phrase 'Grand total' and (in red) the figure 80. From so shattered a document not too much can be drawn, but at least it is evident that on occasion a variety of officials might have responsibility for supplying (through subordinates) definite quantities of brick for a royal temple. The figure ' 80 ' for 17 officials seems remarkably small (just over three units per man); if bricks are indeed intended, ${ }^{4}$ then perhaps 80 multiple units are to be understood.

From the Middle Kingdom, the early 12th Dynasty ( $c$. $1970 B C$ ), there has recently been published a series of account-papyri found in Upper Egypt (district of Thinis and Abydos). ${ }^{5}$ While detailed study of these documents poses many headaches for would-be interpreters, yet they do throw vivid light on the closely-organized accounting practised in early-second-millennium Egypt, specifically for building-projects. They present detailed notices of several hundreds of workmen grouped in small gangs generally of 6 to 18 men (occasionally up to 22 men or down to one), each gang being under a named foreman or crew-leader (two terms used). These records include calculations of 'man-days' worked and payment in terms of trsst-loaves (eight per man per day, sometimes seven and a fraction). ${ }^{6}$ This welter of 'contractor's statistics' includes the making and use of mud bricks. In Papyrus Reisner I, section K, occur detailed specifications for 'loosening brick-clay', 'removing(?) water from the field', and of work 'completed in brick-clay of the fields', all 'completed for him in large-size brick'. ${ }^{7}$ An added summary

${ }^{3}$ Cf. Posener-Kriéger and de Cenival, op. cit. 25 and pl. 62; and $c f$. pl. 63.

4 The word for 'brick' ( $d b t)$ can also be used for ingots or 'blocks' of metal (examples, cf. R. O. Faulkner, A Concise Dictionary of Middle Egyptian, Oxford University Press (1962) 321).

${ }_{5}^{5}$ Papyrus Reisner I-IV, Nos. I-III having been published by W. K. Simpson, Papyrus Reisner I, II, III, 3 vols., Museum of Fine Arts, Boston (1963-69).

${ }^{6}$ On trsst, cf. additionally W. K. Simpson, JEA 59 (1973) 220-222 and fig. 1.

7 Simpson, Papyrus Reisner I, 56-58, 126, pls. 15/15A. 
remarks: 'completed for him in brick - 39,118 (bricks) by 602 (enrolled labourers)'. ${ }^{8}$ This yields some 65 bricks produced by each man as his daily stint. ${ }^{9}$ Papyrus Reisner III has further notes on brickmaking. Here, section $\mathrm{C}$ (page $3, g$ ) has a special column of figures for 'serfs making bricks', usually 20 men per day. ${ }^{10}$ Section E, line 14, has: 'assigned for brickwork, enrolled men, 200 [numeral crossed out] men, $[x]+124$; bricks, $3000+[y]$ ', plus further cipherings too damaged to assess. ${ }^{11}$ Section $F$ has notes of "what was fulfilled for him in ferrying straw' or 'in brickwork', while section $\mathrm{J}$ alludes to work on a building 'with bricks of Thinis' (lines 16,25). ${ }^{12}$ Papyrus Reisner III Supplemental is much occupied with brick-clay from various sources, obtained under the eye of minor officials. ${ }^{13}$

Later in the 12th Dynasty (c. $1850 \mathrm{BC}$ ), other fragmentary brick accounts ${ }^{14}$ include the entry: '(Bricks), total, 116,511; details - bricks of 5 palms (dimension); 23,603; bricks of 6 palms (dimension); 92,908, under (an official) ${ }^{15}$ Senbef.' At about the same period, in Year 33 of Ammenemes III (c. $1810 \mathrm{BC}$ ), an official far south in Nubia proudly recorded on a stela the considerable run of bricks he used to build some official structure: 'Amount of bricks that went into the wall which is in (the building called) "Walls of Ammenemes"..., being what was done by the Noble, the unique Companion . . . Intef begotten of Sen-ib:- 35,300 (bricks)'. ${ }^{16}$

Three centuries later, the New Kingdom or Empire period in Egypt's history comes much closer in time to the saga of oppression and exodus. Long famous has been the unique painted scene of an Egyptian brickyard depicted in lively fashion in the rock-cut tomb-chapel of the Theban vizier

${ }^{8}$ Ibir. j1-63, 128, pls. 17/17A.

9 So Simpson, op. cit. 62, 84. On special terminology for (brick)-clay, etc., cf. ibid. $72 \mathrm{ff}$.

10 Simpson, Papyrus Reisner III 20 and pls. 6/6A.

11 Ibid. 32 and pls. 10/10A.

${ }^{12}$ Ibid. 23-25, 34, pls. 12/12A (5:18; 6:13-14; 7:18-19); pls. 17/17A:16, 25.

${ }^{13}$ Ibid. 35-36, pls. 20-21/20A-21A.

${ }^{14} \mathrm{~F}$. Ll. Griffith, Hieratic Papyri from Kahun and Gurob, Quaritch, London (1898) pl. 22:36-40, cf. p. 59. These come from Illahun near Memphis.

15 An obscure title here.

16 From Kerma, south of the Third Nile Cataract; Reisner, Kerma IV-V, 509 (tig. 343:30), 51 1-512, and quoted by H. Fischer, Revue d'Egyptologie 13 (1961) 108. 
Rekhmire c. $1450 B C .{ }^{17}$ A mixed group of workers (Syrians, Nubians, Egyptians) draw large jarfuls of water from a pool, mix water and clay with their hoes, and mould (or 'strike') row upon row of bricks with a hollow rectangular brickmould. One man measures-off a pile of bricks with his hoe, while others carry off yoke-loads of dried bricks ${ }^{18}$ to the building site, shown as a structure reached by a sloping ramp. Among the men, Egyptian overseers (each armed with a slim baton) sit or stroll keeping vigil over the work in progress. While the number of people depicted may simply be adventitious, there seem to be nine or ten men per overseer. In this scene, it is the presence of foreigners from the Levant (like the Hebrews) that has so often attracted attention especially as the setting is not the Delta but some hundreds of miles south at Thebes in the vast Karnak temple-precinct of the god Amun. ${ }^{19}$

Under the Ramesside kings, the Anastasi papyri from Memphis preserve some almost equally well-known references to brickmaking. Papyrus Anastasi III, Verso 1:7-9, 3:1-3 (time of Merenptah, $c$. $1220 B C$ ) refers repeatedly to building jobs and goes on (vs. 3:1-3): 'Total, 12 building jobs. Likewise, the men are making ("striking") bricks in their spells-of-duty (??), ${ }^{20}$ bringing them for work in the house. They are making their quota of bricks daily' ${ }^{21}$ - a phrase strongly reminiscent

${ }^{17}$ In W. Thebes, tomb-chapel No. 100, scene (14), V, in B. Porter and R. L. B. Moss, Topographical Bibliography of Ancient Egyptian Hieroglyphic Texts, Reliefs and Paintings, I:1, Oxford University Press (1960) 211-212, with extensive bibliography. Definitive publication, N. de G. Davies, The Tomb of Rekhmire at Thebes, I, II, Metropolitan Museum of Art, New York (1943) 54-56, pls. 58-60, plus idem., Paintings from the Tomb of Rekhmire at Thebes, Metropolitan Museum, New York (1935) pls. 16-17. 'Popular' reproductions are legion; suffice it to cite D. J. Wiseman, Illustrations from Biblical Archaeology, Tyndale Press, London (1958) 44-45, fig. 38 (from Lepsius), or the rough sketch in J. D. Douglas et al. (eds.), The New Bible Dictionary, IVF, London (1962) 166-7, fig. 44.

18 Plus basketloads of mud mortar, and white stone blocks.

19 A fact clearly stated in the label-tex ts to the scene, e.g. 'striking bricks to build workshop-stores anew for Karnak'. Or, over a Syrian,' 'Spoils (=captives) brought by His Majesty (=Tuthmosis III) for the work of the temple of his father [Amun]'.

${ }^{20} \mathrm{Bk}$, a word otherwise unattested; from the sun-disc determinative, one might expect an expression of time.

${ }^{21}$ Sir A. H. Gardiner, Late-Egyptian Miscellanies, Fondation Egyptologique Reine Elisabeth, Brussels (1937) 30-31, in hieroglyphic transcript; a translation with commentary in R. A. Caminos, Late-Egyptian Miscellanies, Oxford University Press (1954) 105-106. 
of Exodus 5:8, 13-14, 18-19. In more ribald vein, a sardonic passage in Papyrus Anastasi IV, 12:5-13:8 (time of Sethos II, c. $1210 \mathrm{BC}$ ) portrays an official posted out in some death-trap of a border-post, devoured by insects and haunted by jackals and wild dogs. Among his ills, "there are no men to mould bricks and no straw in the district'. ${ }^{22}$ A variety of stampimpressed bricks are known, not least of the notorious Ramesses II. ${ }^{23}$ Two ostraca of the 13 th century $B C$ from the workmen's village at Deir el-Medina (W. Thebes) include mention of bricks. The first mentions: '[Amounts?] of bricks made for the Do[or ... ]. [Workmen of] the Right Side: SiWadjyt, 100; [ .....x .. ], 100; Pennub, [rest lost ] '. ${ }^{24}$ Among very varied accounts, the other includes 'bricks, 250'. ${ }^{25}$ Finally, a scrap of papyrus from Gurob (' $Z$ ') near the Fayum once listed personnel to whom bricks had been issued, totalling over 39,000 , plus a note of 760 other bricks. ${ }^{26}$

However, a much more extensive document can now be added to the textual data on bricks in Egypt. First published eighty years ago and neglected ever since, this is the "Louvre Leather Roll', dated to Year 5 of Ramesses II. ${ }^{27}$ This document was used as an erasable 'notepad', whereon one set of notations (once finished with) might simply be washed off in favour of new accounts and calculations. The present columns II to IV:2 open with the heading (II:1), 'The Great Stable of Ramesses (II) Beloved of Amun', followed by the names of

${ }^{22}$ Gardiner, op. cit. 48-49; Caminos, op. cit. 188-9. The first sentence cited here (on bricks and straw) reappears in Papyrus Anastasi V, 3:1 of the same date (Gardiner, 57; Caminos, 225).

${ }^{23}$ For Ramesses II, cf. B.M. 6020; see photo in Wiseman, op. cit. 43, fig. 37, or New Bible Dictionary, pl. III $b$.

${ }^{24}$ Ostracon Gardiner 93, probably of time of Sethos II; copy and hieroglyphic transcript in J. Cèrny and Sir A. H. Gardiner, Hieratic Ostraca I, Oxford University Press (1957) 13, pls. 44/44A, No. 5; not previously translated.

${ }^{25}$ Ostracon Liverpool 13625, of about Merenptah's reign, in Cerny and Gardiner, op. cit. 18, pls. 63/63A, No. 3, recto, line 7.

${ }^{26}$ Hieroglyphic transcription, Gardiner, Ramesside Administrative Documents, Oxford University Press (1951) 34 (cf. p. xii, § XV). The second entry is from Year 22 of Ramesses II or III (i.e., c. 1270 or c. $1180 \mathrm{BC}$ ). The personnel involved are very diverse: builders, metalsmiths, cobblers, keeper of a granary.

${ }^{27}$ Bought in Thebes; published by P. Virey, Memoires de la Mission Archeologique Française au Caire, I, Paris \& Cairo (1893) 481-510, pls. I-V, What follows in this paper is based on the writer's new and revised hieroglyphic transcription of this document (ultimately to appear in Ramesside Inscriptions, II), as Virey's transcription can now be improved upon. 
40 "stablemasters" 28 (as 'X son of Y'). Opposite each such name is the production-target of ' 2000 bricks', and then figures for actual deliveries so far as recorded (nil to six entries), sometimes totalled up. The fullest example (in II:6) runs as follows: 'Yupa son of Urhiya, (target) 2000 bricks: 660 arrived, 410 arrived, 560 arrived. Total, 1630; deficit, 370.' But few reach a total, and some are "non-starters". A target of 2000 bricks each for 40 men would imply a total target of 80,000 bricks to be produced over an unknown period of time (Virey suggested a month). Elsewhere in the document, one heading (col. VIII:1) runs, 'Year 5, 1st month of Shomu [Summer], Day 2; copy(?) of receipt of bricks from . . (someone)', followed by numbers of bricks for Days 2 to 6 of that month (totalling 12,390 bricks), and then for Days 9 to 14 explicitly totalled at 15,200 bricks; the grand total would be 27,590 bricks. The next heading (IX:1) reads '1 st Shomu, Day 2: delivery (or, transport) of bricks', with quantities of bricks for Days 2 to 6 that amount to 22,890 bricks. This last figure tallies neither with those of col. VIII (partial or overall) nor with the total of deliveries ascertainable in cols. II-IV:2 (at 25.505). Thus, the accounts in cols. II-IV:2, VIII and IX cannot be correlated at present.

But, whatever the arithmetical obscurities, one may be sure that the actual making of all these bricks was performed not by the stablemasters - junior officers, in fact ${ }^{29}$ - but by gangs of men working under them. The same probably applies to further sections of the roll where 17 men provide wooden beams (col. V; usually 3 each), and make delivery of bundles of reeds (col. VI - lots of 305 and 680), and again with 'stablemasters who bring beams to the house' (VI:12, seven men, eight beams). The association in one document of bricks, wooden beams and bundles of reeds is no mere accident. Plus sand, these are three basic elements used in making constructional scaffolding when arecting the massive stone temples so

${ }^{28}$ The actual title (hry ihw) is attested for at least five or six of the men elsewhere in the scroll (cols. VI, XI). Large groups of 'stablemasters' are attested elsewhere - e.g. 20 together on a major quarrying expedition under Ramesses IV, c. $1150 \mathrm{BC}$ (Kitchen, Ramesside Inscriptions, VI/1, Blackwell, Oxford (1969) 14:4-5).

${ }_{29}$ Yupa son of Urhiya (a good Hurrian name!) would be in his twenties in Year 5 of Ramesses II, as he had become a high official by Year 54 of that king, proclaiming then the 9 th Jubilee - when he must have been in his seventies. 
characteristic of New Kingdom Egypt. From this same reign (Ramesses II), the Satirical Literary Letter (Papyrus Anastasi I) sets as a "practical problem" the calculation of the number of bricks required for 'a ramp 730 cubits (long), breadth 55 cubits, consisting of 120 compartments, filled with reeds and beams, with a height of 60 cubits at its summit ...'30 The combination of bricks in a ramp, plus blocks, beams and reed mats, is reflected in parts of the famous scene of brickmaking and building in the tomb-chapel of the vizier Rekhmire already mentioned above.

One other detail of interest in the Louvre Leather Roll is a short section near the end (col. $\mathrm{X} b$ ) which begins: 'Documents (lit., 'writings') which belong to the leaders, in their possession'. This heading is followed by five identicallyphrased entries each reading 'the document of (So \& so), 1 skin' - i.e., one leather scroll of the type of the Louvre Leather Roll itself. ${ }^{31}$ This would confirm the use of such leather scrolls for ephemeral work-accounts that could be erased and replaced repeatedly.

Secondly, the biblical data that form our starting-point may be summed up thus. In Exodus 1:11-14, 'taskmasters' (śäre-missim) were set over the Israelites to keep them in subjection through forced labour - hard servitude ('aboda $q a s \bar{a} \bar{a}$ ) in mortar, in brick, and in all (kinds of) servitude in the field, with rigour. From Exodus 5:5ff., we learn that the brickmaking Hebrews had to produce a definite quota but were normally given straw or chaff for their task until Pharaoh decreed that they should find their own straw but still main tain their output, he being incensed at Moses' request for time off for the Hebrews to worship their God in the wilderness. We see also a two-tier administration between Pharaoh and the Hebrew labourers. General oversight fell to Pharaoh's 'taskmasters' (here, nogesim) who chose some of the Hebrews as 'foremen' (soterim) over their fellows. These foremen were directly responsible to the royal 'taskmasters' for the

${ }^{30}$ Papyrus Anastasi I, 14:2-3, in Gardiner, Egyptian Hieratic Texts, I/1, Hinrichs, Leipzig (1911) $16^{*}-17 *, 25$ (passage omitted in $A N E T$ ).

${ }^{31}$ Papyrus was the normal manuscript material (see J. Cerny, Books \& Paper in Ancient Egypt, Lewis, London (1952)), with ostraca for lesser jottings. Surviving leather scrolls are much rarer (cf. A. Lucas \& J. R. Harris, Ancient Egyptian Materials \& Industries, ${ }^{4}$ Arnold, London (1962) 364), other specimens being found in the British and Cairo Museums (loc. cit.), plus Berlin and the Louvre (e.g., G. Moller, Hieratische Paloographie, II, Hinrichs, Leipzig (1927) 4, n. 1). 
fulfilment of the daily quotas of bricks by their fellowHebrews, and could be beaten as punishment for deficits (5:14).

Thirdly, some correlation of the Egyptian data with Exodus 1 and 5 may be essayed under three rubrics: levels of authority, control of work, and miscellaneous points.

Levels of authority. The two-tier oversight of the labouring Hebrews corresponds with known Egyptian usage, both explicit and implicit, both in building and in agriculture. In agriculture, land belonging to an institution is cultivated (i) $r$ - $h t$ ' under the authority' of a high official, and (ii) $m$ - $d r t$ 'by the hand/agency of' some lesser person, the actual farming work being done by this person or by farm-labourers under him. ${ }^{32}$ What is explicit in the basic occupation agriculture is also explicit in one especial 'building community', that of the workmen responsible for the royal tombs in the Valley of the Kings, based on the village whose ruins are now known as Deir el-Medina. ${ }^{33}$ Here, the twin gangs of workmen were led by two foremen appointed from their own number (as were the Hebrew soterim) who, along with two scribes, were directly responsible in their case to the Theban vizier himself as their superior officer. In the more ordinary building and brick accounts reviewed briefly above, the two-tier arrangement is more implicit than explicit, but is nonetheless presupposed. Thus, in the Old Kingdom Abusir papyri, the various palace officials would not themselves have made or furnished bricks for a royal funerary temple; below them must have been workmen and foremen to make and account to them for the bricks required. Among the Middle Kingdom documents cited above, the Reisner papyri with their building-gangs of 6 to 18 men per foreman illustrate the lower segment of administration, and must have been responsible to officials in charge of the building-project

${ }^{32}$ Cf. Gardiner, The Wilbour Papyrus, II: Commentary, Oxford University Press (1948) 19; B. Menu, Le régime juridique des terres et du personnel. . . Papyrus Wilbour, Institut de Papyrologie et d'Egyptologie, Lille (1970), 11-15. On scope of use of the term 'cultivator' (tenant-farmer employing others and farmlabourer), $c f$. Gardiner, JEA 27 (1941) 21-22.

${ }^{33}$ On which, see briefly J. Cerny, $C A H^{2}$, II, Chapter 35, section III; fuller, idem, $A$ Community of Workmen at Thebes in the Ramesside Period, and The Valley of the Kings, IFAO, Cairo (1973). 
concerned ${ }^{34}$ - doubtless, men of the standing of that proud official Intef who turned 35,300 bricks into 'the Walls of Ammenemes' in Nubia. Closer in time to the exodus, from the New Kingdom data, the Louvre Leather Roll with its 40 stablemasters in charge of brick-production offers us counterparts to the nogeśim, 'taskmasters', of Exodus 5; these 40 men would each have charge of gangs of labourers led by foremen (as at Deir el-Medina, and earlier in the Reisner papyri). The nogeśim of Exodus 5 would most likely have been just such junior officers/officials as the stablemasters of the Louvre Leather Roll. ${ }^{35}$ And the Hebrews may likewise have been organised in gangs of 10 or so men under their foremen. ${ }^{36}$

Control of work. In Exodus 5, much emphasis is laid on the Hebrews' fulfilling their production-targets for bricks, straw or no straw. This seems particularly true to the emphasis visible in Egyptian documents, be it the meticulous calculations of payable man-hours in the Reisner papyri, or the target (2000) and amounts received for bricks set against the 40 stablemasters of the Louvre Leather Roll, or the long familiar reference in Papyrus Anastasi III to men 'making their quota of bricks daily', and so on. Some of the accounting (e.g. Pap. Reisner) is suffocatingly precise, down to the last brick - e.g. 39,118 or 116,511 - at least in principle. Likewise comparable is Egyptian sensitivity to holidays or at least time off. In the Louvre Leather Roll cols. VIII and IX, no brick-deliveries were made on Days 1, 7 and 8 of the 1 st month of Shomu. These days, therefore, may reflect either 'rest days' (for issue of rations, etc.) or occasions of public festival; 1st Shomu, Day 1, was the date of the feast of the goddess Renenutet (a harvest-festival), for example. ${ }^{37}$

34 The unnamed 'him' in headings such as work 'completed for him' may (if rightly construed) allude to the unnamed official in charge.

${ }^{35} C f$. the supervisors with batons in the scene from the tomb-chapel of Rekhmire. For a stablemaster using the big stick freely, cf. Paipyrus Bologna 1094, 3:1-3 (Gardiner, Miscellanies, 3; cf. Caminos, Miscellanies, 12): '(As for) the cultivators of the land of Pharaoh under the authority of my lord, two men of these fled from before the Stablemaster Neferhotep, as he beat them.'

${ }^{36}$ Even in the afterlife, Egyptian servant-figures ('shabti-figures') were sometimes organised in gangs of ten with 'overseer'-figures.

${ }^{37}$ Cf. S. Schott, Altagyptische Festdaten, Steiner, Wiesbaden (1950), 103; for holidays at Deir el-Medina on 1st Shomu, 1, 7, 8, cf. Helck, Journal of the Economic \& Social History of the Orient 7 (1964) 150 (table), 158: 20. What festivals occurred on Days 7 and 8 is as yet unknown. 
In Exodus 5:1 Moses quite freely requests time off for a religious feast, while the king is distinctly less enthusiastic, particularly for a deity he professes not to know of. As has been remarked elsewhere, ${ }^{38}$ the 'worksheets' of attendances and absences from Deir el-Medina include numerous days when workmen were 'idle', including men who went 'to offer to their god'; the pharaoh, therefore, might well have been chary of allowing any additional holidays!

Miscellaneous points. Exodus 1:14 speaks of 'mortar' (homer) and brick. In Egypt, the normal mortar used with mud brick was simple clay mortar, i.e., clay, sand and water, ${ }^{39}$ which meaning should be understood of the Hebrew word here as elsewhere. ${ }^{40}$ The use of straw or chaff - tibn in Arabic, and used for such bricks even today - needs no additional comment here. ${ }^{41}$ The šoterim or 'foremen' is usage that not only fits the Egyptian setting in this case but is also consistent with the use of this word in the rest of the Old Testament right down to Chronicles; in very varied contexts, the šoterim tend to be lesser officials and organisers. ${ }^{42}$.The word nogesim in Exodus 5 is a general term for 'taskmasters' (driving people on), while the säré-missim of Exodus 1:11-14 is slightly more specific, 'directors of forced labour', insofar as missim is probably a plural form of mas, 'forced labour, corvee', the latter word being attested in cuneiform sources of the second millennium BC. ${ }^{43}$ Finally, what in fact, were the Hebrews building? Only Exodus 1:11 is specific - 'storecities, Pithom and Ra'amses'. Of Pithom, little can be said for the moment. But $\mathrm{Ra}^{6}$ amses is well recognised as the Delta capital Pi-Ramesse, where were to be found palaces, houses, offices, stores, barracks, etc., all of mud brick, besides temples

${ }^{38}$ Kitchen, Ancient Orient \& Old Testament, Tyndale Press, London (1966) 156-7 and references.

${ }^{39}$ Gypsum being reserved for use with stone, not brick; $c f$. Lucas \& Harris, Anc. Eg. Materials \& Industries, ${ }^{4}$ (1962) 74-75.

$4^{\circ} C f$. Nahum 3:14, 'Go into the clay (tit) and tread the mortar (homer)...', and use of homer for clay for pottery (Jer. 18:4, 6), impressed by a seal (Job 38:14), besides mere mire (Is. 10:6).

${ }_{41}$ References, Kitchen, Ancient Orient \& OT, 156, nn. 12-13, and New Bible Dictionary, 168.

${ }^{42}$ And not necessarily scribes (despite this meaning of the Akkadian cognate sataru). For two illuminating contexts of late date, cf. $2 \mathrm{Chr}$. 26:11 (scribe and a soter serving under higher royal officials) and 34:13 (scribes, officers (soterim) and porters, as three entities). 
of the principal gods of empire, of stone but erected by use of 'scaffolding' and ramps of mud brick, wood and reeds, and enclosed within large precincts walled massively with mud brick and containing many subsidiary structures built in brick. In this bustling new capital, intended to rival both Memphis and Thebes, ${ }^{44}$ the Hebrews (and others) would certainly not lack employment nor their products ample uses, especially if it were at the command of Ramesses II, quantitatively the greatest of all Egypt's builder-kings. ${ }^{45}$

${ }^{43}$ E.g., Amarna letters, Mendelsohn, BASOR 143 (1956), 20, n. 33; his reference to Ugaritic $m s m$ (n. 32) should be deleted (also from Anc. Orient \& OT, 159, n. 23), as the true reading is $m d m$ - so, Virolleaud, Syria 21 (1940), 149, and A. Herdner, Corpus des Tablettes. . . Ras Shamra-Ugarit, I, Imprimerie Nationale \& Geuthner, Paris, (1963) 165 \& n.1.

44 Pap. Anastasi II, 1:2-3.

45 Like the Apiru dragging stone for a Memphite pylon of Ramesses II, Pap. Leiden I 348, verso 6:5-7 (Miscellanies, ad loc.). 